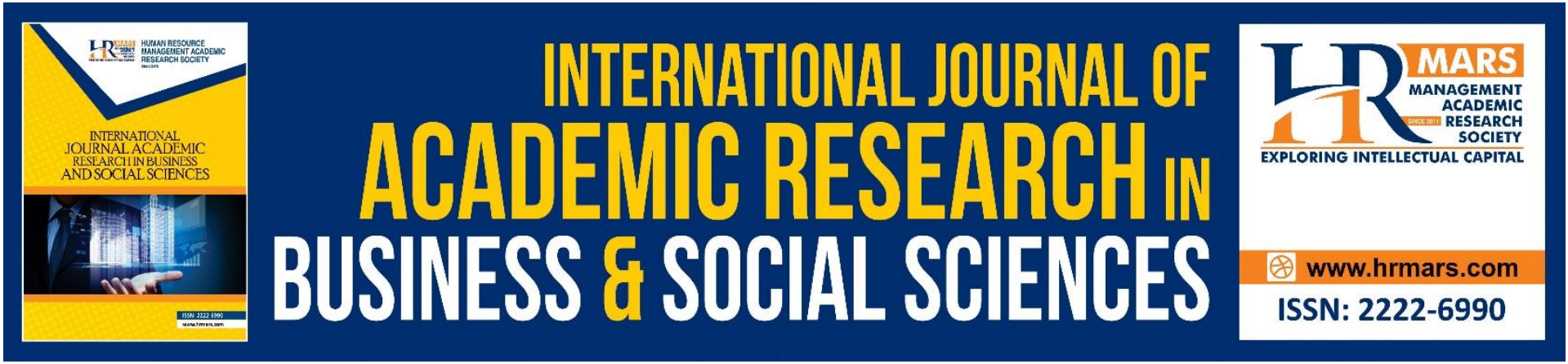

\title{
The Association of Information and System Quality toward User Intention in Using Self-Service Technology
}

\author{
Areena Dalila Mohd Din, Mohd. Khirzanbadzli A Rahman, Abdul Kadir \\ Othman, Wan Edura Wan Rashid, Maz Jamilah Masnan, Ismael AbuJarad
}

To Link this Article: http://dx.doi.org/10.6007/IJARBSS/v11-i11/11474

DOI:10.6007/IJARBSS/v11-i11/11474

Received: 07 September 2021, Revised: 10 October 2021, Accepted: 27 October 2021

Published Online: 19 November 2021

In-Text Citation: (Din et al., 2021)

To Cite this Article: Din, A. D. M., Rahman, M. K. A., Othman, A. K., Rashid, W. E. W., Masnan, M. J., \& AbuJarad, I. (2021). The Association of Information and System Quality toward User Intention in Using Self-Service Technology. International Journal of Academic Research in Business and Social Sciences, 11(11), 2423-2433.

Copyright: (c) 2021 The Author(s)

Published by Human Resource Management Academic Research Society (www.hrmars.com)

This article is published under the Creative Commons Attribution (CC BY 4.0) license. Anyone may reproduce, distribute, translate and create derivative works of this article (for both commercial and non0-commercial purposes), subject to full attribution to the original publication and authors. The full terms of this license may be seen at: http://creativecommons.org/licences/by/4.0/legalcode

Vol. 11, No. 11, 2021, Pg. $2423-2433$

Full Terms \& Conditions of access and use can be found at http://hrmars.com/index.php/pages/detail/publication-ethics 


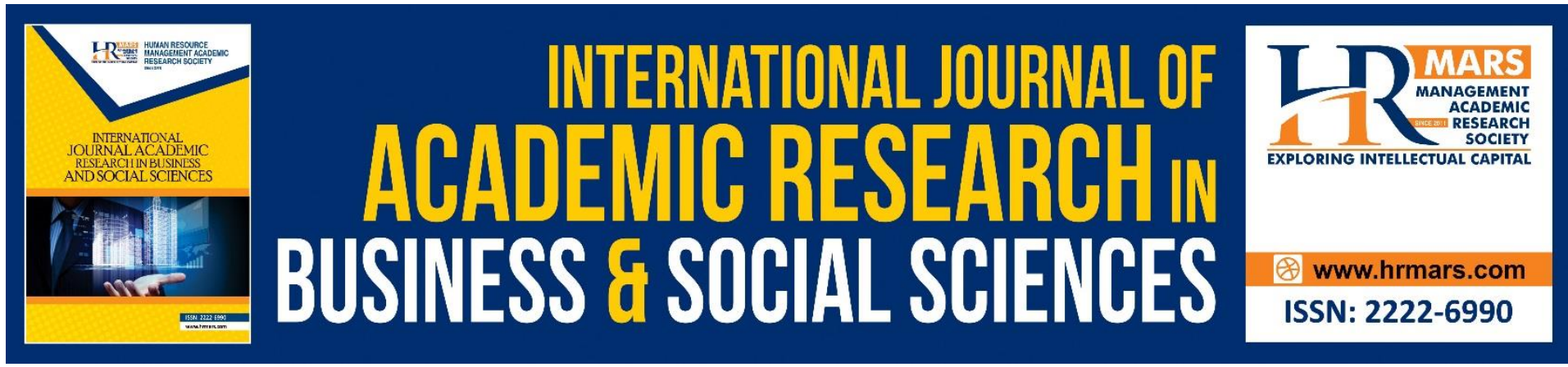

\title{
The Association of Information and System Quality toward User Intention in Using Self- Service Technology
}

\author{
Areena Dalila Mohd Din ${ }^{1}$, Mohd. Khirzanbadzli A Rahman²\&3, \\ Abdul Kadir Othman ${ }^{2 \&} 3$, Wan Edura Wan Rashid ${ }^{2 \& 3}$, Maz \\ Jamilah Masnan ${ }^{4}$, Ismael AbuJarad ${ }^{5}$
}

${ }^{1}$ Pos Malaysia Berhad, 50100 Kuala Lumpur, MALAYSIA, ${ }^{2}$ Institute of Business Excellence, Universiti Teknologi MARA, 40450 Shah Alam, Selangor, Malaysia, ${ }^{3}$ Faculty of Business and Management, 42300 UITM Cawangan Selangor, Selangor Darul Ehsan, Malaysia, ${ }^{4}$ Centre of

Excellence Social Innovation \& Sustainability, Universiti Malaysia Perlis, Kampus Alam UniMAP, 02600 Arau, Perlis, Malaysia, ${ }^{5}$ Faculty of Economics and Administrative Sciences, Istanbul Aydin University, Küçükcekmece, Istanbul

TURKEY

Emai: khirzan@uitm.edu.my

\begin{abstract}
Self-service technology (SST) has been constantly changing. The advancement in communication and information technology has driven customers in Malaysia to perform selfservice transactions and consequently such activities are expanding. Among the factors that are said to influence customers to adopt SST are Information and System Quality. Thus, this study was undertaken to confirm the association of Information and System Quality on User Intention to use SST. After studying several companies that provide SST, one of the courier service companies in Malaysia was chosen to participate in the study. This company provides SST facilities in the business interactions with their customers. The items for the research instrument were adopted and adapted from past studies and distributed to 200 walk-in SST users of the courier service company. The data were analyzed using descriptive analysis, factor analysis, reliability, Pearson Correlation Coefficient Analysis using IBM SPSS Statistics version 25 . The results demonstrated that completeness, format, reliability, accessibility, flexibility, and integration had significant relationship with user intention. Meanwhile, accuracy, currency and timeliness were found to have no significant relationship with user intention. The study provides practical recommendation and suggestion for future research improvement.
\end{abstract}

Keywords: Self-Service Technology, Information Quality, System Quality, On-line Shopping, User Intention

\section{Introduction}

Malaysia's revenue for the service sector has been increasing obviously due to the growth of 
e-commerce which has been supported by the advanced information and communication technology. The information and communications sub-sector was also proposed to accelerate its growth to $6.9 \%$ in 2020 , in contradiction of a $6.7 \%$ estimated growth in 2019 , due to the introduction of $5 \mathrm{G}$ technology. The income for the service sector in Malaysia has improved by $6.5 \%$ to RM441.3 billion in the subsequent quarter of 2019 (2Q19), from RM414.2 billion in the same period last year (Department of Statistics Malaysia, 2019). Thus, to ensure that the services provided will be able to meet the needs of consumers, technology is important so that processes can be expedited. One of the initiatives to gain a better outcome is by using self-service technology (SST).

Over the years, SST has been consistently improving. With the advancement in communication and information technology, more customers in Malaysia have been using SST and the number of users is increasing. Although most customers have overcome their worries of SST and have access to hi-tech services, they are still exposed to anxiety and uneasiness while using these services. Experts generally argue that SST signifies an important element in today's retail environment, proposing convenience for many patrons, along with long-term cost savings obtained by providers (Collier \& Barnes, 2015). In Malaysia, many organizations in the service industry have implemented SST to expedite the services offered to customers. For instance, the banking industry provides automated teller machine (ATM), cash deposit machine (CDM) and internet banking in-line with its SST. The transportation industry provides self-check-in kiosks for passengers to check-in their tickets in the airline services. There are many other examples of SST available in Malaysia. Meuter, Ostrom, Roundtree and Bitner (2000) said that SST has four main types namely telephone-based SST such as telephone banking, internet-based for online shopping, kiosk-based such as ATM, and video or compact disc (CD) based for instance CD-based training. Based on these examples, this study has identified a courier service company that provides the SST facilities to its customers, hence, making it eligible to be the focus of research.

The Malaysian Communication and Multimedia Commission (MCMC), granted under the Postal Services Act 2012 (PSA 2012), is responsible to overseeing and regulating the postal and courier services in Malaysia. Any postal and courier services company must get the approval from MCMC to operate in Malaysia. Some examples of postal and courier service companies available in Malaysia are Pos Malaysia Berhad, Nationwide Express Courier Services Berhad, GD Express Sdn. Bhd., City-Link Express (M) Sdn. Bhd., DHL Express (M) Sdn. Bhd., United Parcel (M) Sdn. Bhd., NCT Forwarding \& Shipping Sdn. Bhd. and Yamato Transport (M) Sdn. Bhd. As of 2019, MCMC has released more than 116 licenses including to major transnational courier players to upkeep the rising e-commerce industry. Some courier service companies in Malaysia have taken drastic measures to improve the national postal system for the benefit of all citizens including those residing in urban and rural areas (MCMC, 2019). From our initial investigation, the chosen courier service company has introduced selfservice technologies (SSTs) since the year 2009 to cope with the customers' high expectation for excellent services.

Fast and quality services are important for any service sector. Every customer requires efficient services regardless of the type of services the company provides. In 2018, it was reported that the selected courier service company received many complaints especially via the social media platforms regarding the quality of its delivery services (The Borneo Post, 2018). Consequently, the company had been directed by the Minister of Communication and Multimedia to review its entire postal system. Nevertheless, the postal and courier services continue to receive complaints amounting 2,102 in 2019 and the result showed an increase 
of $70 \%$ from 1,235 cases in 2018 . The MCMC has reported that the number of complaints showed a significant increase from 2015 (143), 2016 (200), 2017 (414), 1,235 (2018) and 2,102 (2019). The rising number of complaints is due to higher e-commerce transactions volume particularly during the major online sales such as the 11.11 Online Sales (MCMC, 2019) and it is predicted that the number of complaints will increase in the future due to the rapid usage of e-commerce.

However, the usage of these SSTs was not popular among the customers. The data also disclosed that several users were not encouraging. For example, based on the given data, some of the SSTs are available in the post offices have shown zero usage and were not meeting the target registered by the department in-charge whereby, the daily average usage target is 25 to 70 items of users per day for each individual Dropbox, Ezibox and Post Automated Machine (Pos Malaysia Berhad, 2017). Meanwhile, Zohoori, Nabuzadeh, Asgharian and Bekheirnia (2012) stated that in order to ensure users intend to keep using the SST, it is crucial to ensure users are satisfied with all the information on the SSTs. Thus, it is essential and insightful to grasp under what circumstances customers would use self-service as opposed to personal service (Cheng, Harris, \& Patterson, 2012). Although abundance of studies has been conducted and various measures have been taken to address the issue, the present study was undertaken to:

- examine the relationship between information quality, system quality and user intention

- $\quad$ identify the most influential factor of user intention towards using SST at the selected courier service company.

\section{Literature Review}

This research aims to study the influence of information and system quality on user intention towards sst at the selected courier service company in klang valley. User intention refers to the individual's readiness to engage in a particular behavior. The individual's attitude towards a behavior influences the intention to act (Mafabi et al., 2017).

\section{User Intention}

Organizations are required to enhance their SSTs regardless of customers with different levels of adoption or attitude, as it will give impactful intention to continuously use the SSTs. In accordance with the Technology Acceptance Model (TAM), user intention to use SST is demonstrated by the degree of strength in attitude and intention to use technology. The intention to use authorized services is influenced mostly by "perceived ease of use" and "perceived usefulness" (Davis, Bagozzi, \& Warshaw, 1989). In this study, Information Quality (IQ) and Service Quality (SQ) will obviously display whether a patron will leave or remain with the business by endorsing the company's goods and services. Besides, a customer is ready to give commitment towards the organization in terms of loyalty.

\section{Information Quality}

IQ measures semantic success, which is the user's perception of the value of the information presented by the SSTs to the user. DeLone and McLean (2002) said that information quality denotes the quality of outputs the information system produces such as reports or online screens. According to Wixom and Todd (2005), the factors that create an individual's information satisfaction are completeness, accuracy, format, and currency of the information provided from a technology. Completeness is an influential determinant for a predefined 
report (Hala \& Habin, 2013). In a website, completeness is one of the determinants of IQ. According to Bailey and Pearson (1983), completeness is the extensiveness of the output information content. For example, users found information on a company's SST is adequate for the task at hand. This means, meeting the expectations of the public is a vital aspect and ensuring the re-use of the SST.

Hala and Habin (2013) stated that for all business intelligence tools, accuracy appears as the greatest influence on information quality. This indicates that the information that users received has quality and can be trusted when accuracy exists. The next important element in IQ is format. The SST has top notch information contents that are helpful and relevant to the users. The information must be up to date, completed and at the same time having a format that is easy to understand. Consequently, the user's view of the usefulness of SST is probably going to be impacted when users are satisfied with the information provided. Currency is the final element in IQ. Nowadays, users demand to get real time information from the service provider. Besides, users also expect the information to be up to date.

\section{System Quality}

SQ measures technical success, the performance of the information delivered to the users. Wixom and Todd (2005) suggested that the dimensions for SQ consists of reliability, flexibility, integration, accessibility, and timeliness. Reliability denotes the trustworthiness of system's procedure or operation. The system must be reliable to make SST working as promised such as technically functioning well and the accuracy of its service (Weijters et al., 2007). As suggested by Narteh (2015), reliability is precarious because it embeds the dynamic capability to execute the service unfailingly and correctly. For example, in the ATM situation, reliability implies the ability of the machine to function at any time, deliver zero error and constant service.

Flexibility refers on how the system adapts to changing needs of the user. Baykasoğlu \& Özbakır (2008) stated that flexibility has a positive effect on the manufacturing system performance. Thus, it must be accurately utilized by the manufacturing control system to ensure the system runs smoothly. Integration refers on how the system permits data to be integrated from various sources. Webster-Doyle (1991) said that integration is the act of bringing the parts together to make the whole unit. Within an organization, integration comprises handling the framework of people, tools, and relationships to permit consistent, coordinated progress in leveraging information and technology assets. The reason for this is to facilitate effective business processes and gain competitive advantage.

Accessibility is the ease of user that enables information to be assessed or mined from the system. As for the service process, the easiness to use the automated menu system is vital. Furthermore, the "automated menu system" must be able to assist customers to speedily perform the transaction (Suzanne, Susan \& Jeffrey, 2009). Finally, timeliness that denotes the degree to which the system offers quick responses to requests for information. Bailey and Pearson (1983) described timeliness as the availability of the information when required. The system is required to provide timely information and give fast responses when requested, in other words, no hiccups or delay in delivery of information to the users.

The conceptual framework for this study is based on the review of the literature. The model can realistically depict relationships between the independent and dependent variables as illustrated in Figure 1. The first group of the independent variables is known as IQ that consists of completeness, accuracy, format, and currency. Meanwhile, the second group of the 
independent variables reflects SQ comprising reliability, flexibility, integration, accessibility and timeliness (Wixom \& Todd, 2005).

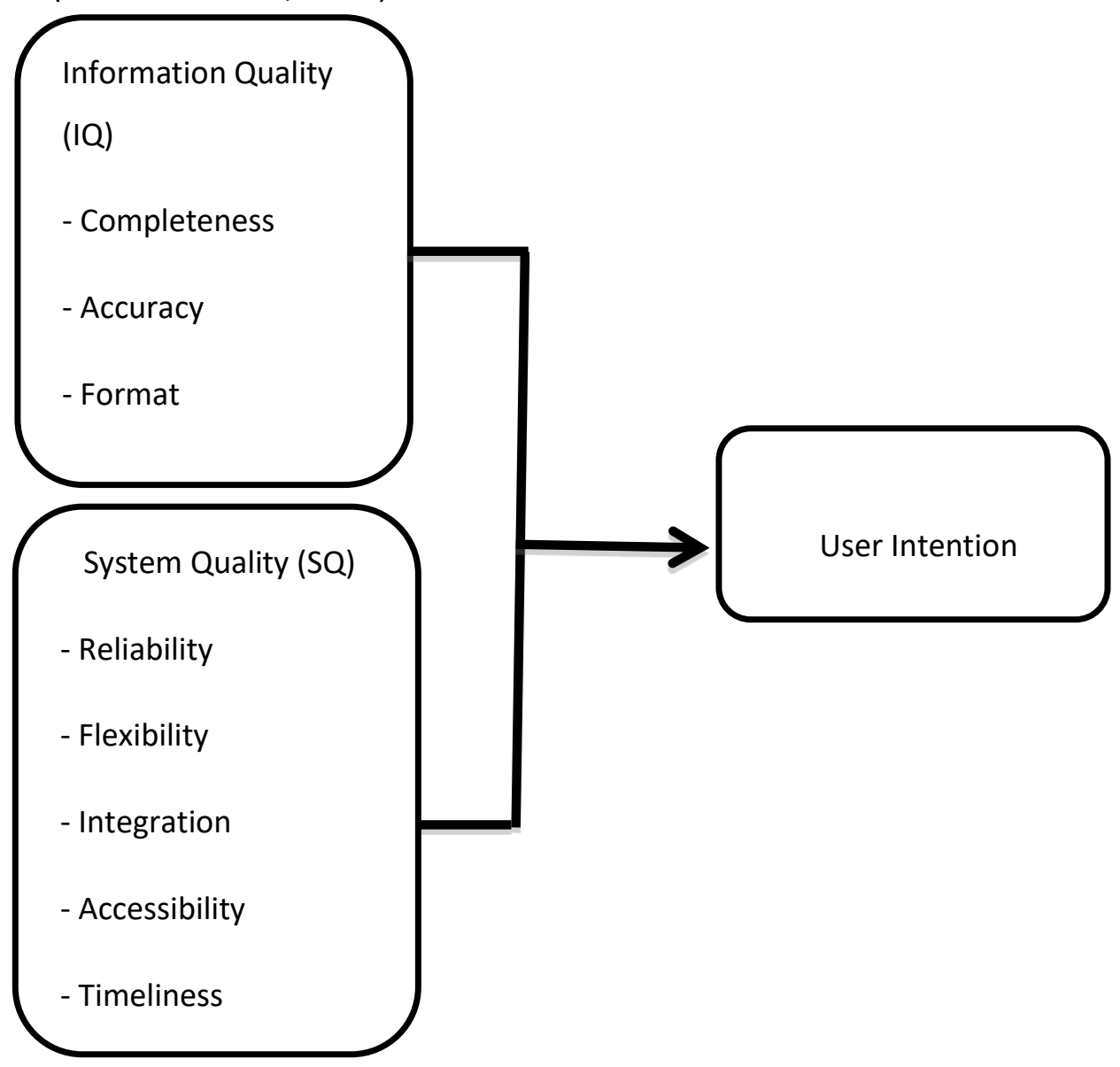

Figure 1: Conceptual Framework of the Study

\section{Methodology}

Based on the examples of SST, the researchers have searched several companies in Malaysia that provide SST and apparently, there are several companies in different industries providing SST. Companies provide machines and kiosks to enable their customers performing SST for any business transaction. After searching many relevant companies that provide SST, the researchers have identified a company, which is one of the largest courier services in Malaysia. Hence, this company was selected to participate in this study.

The target population of this study is the customers of the selected courier service company in Klang Valley, which consists of the state of Selangor, Wilayah Persekutuan Kuala Lumpur and Wilayah Persekutuan Putrajaya. Customers of this company were chosen because they have experienced using SSTs facilities offered by this company as compared to other courier service companies in Malaysia. The reason for choosing Klang Valley for this study is because SSTs are available at many branches of this courier service company in this location.

The total population in Klang Valley for the year 2019 is 8.39 million (Department of Statistics Malaysia, 2019). However, the target population of the selected company who have experienced using SSTs during this study period was unknown. The record showed that on average the utilization rate from January until October 2019 was around 30\% for the two SST services; "drop" and "collect" items. Meanwhile, for the automated machine facilities, about $75 \%$ had been utilized by users. 
Questionnaires were used as the instrument for data collection. They were adopted from Wixom and Todd (2005). The questionnaire used a five-point Likert scale to gauge the respondent's degree of agreement based on five options; (1) "Strongly Agree", (2) "Agree", (3) "Neither Agree nor Disagree", (4) "Disagree" and (5) "Strongly Disagree". User intention was measured using three statements, information quality was assessed by using 12 items and system quality was measured using 15 statements. All statements for each variable were adopted from Wixom and Todd (2005). The IBM SPSS Statistics Version 25 was employed for data analysis.

\section{Findings and Discussion}

Table 1 shows that there were 200 respondents participating in the study, which comprise 99 (49.5\%) males and 101 (50.5\%) females. Majority of the respondents were aged below 30 years old. About $70(51.5 \%)$ respondents were aged between $31-40$ years old. A total of 24 (12.0\%) respondents were aged between $40-50$ years old and three (1.5\%) respondents were above 51 years old. Majority of the respondent's race, 147 (73.5\%) were Malay, 36 (18.0\%) were Chinese, 16 (8.0\%) were Indian and 1 (0.5\%) was classified as other races. The results also showed that $19(9.5 \%)$ respondents earned master's degree, 50 (25.0\%) had a bachelor's degree, 64 (32.0\%) had a diploma and 57 (28.5\%) possessed a higher School Certificate. Regarding employment status, 31 (15.5\%) respondents were students, 49 (24.5\%) were working in the private sector, 59 (29.5\%) worked for the government sector, seven (3.5\%) were retirees and six (3.0\%) were classified as others. Four or $2 \%$ of the respondents earned RM10,000 to RM15,000 monthly, 24 (12\%) earned RM5,000 to RM 10,000 per month and 172 (86\%) earned below RM5,000 per month.

For factor analysis, several statistical values were observed to establish the dimensionality of the items. This can be accomplished by examining the values of "Measure of Sampling Adequacy" (MSA), "Kaiser-Maiyer-Olkin" (KMO), and "Bartlett's test of Sphericity". It is suitable to proceed with the factor analysis if the value of the test is large and significant $(p<0.5)$ (Hair, Black, Babin, Anderson \& Tatham, 2006). For factor loading in the analysis, the threshold value of 0.5 as suggested by Hair et al., 2006 was used. Principal component factor analysis with varimax rotation was used to determine factor's dimensionality. The KMO value of 0.753 indicates that the items are related to each other. Meanwhile, "Bartlett's Test of Sphericity" shows a significant value with Chi Square approximation of $3110.492(p<0.001)$, signifying the significance of correlation matrix and appropriateness of factor analysis.

The outcome of the factor analysis shows that the nine extracted factors resemble the original concepts, three items measure reliability, explaining $21.256 \%$ of the variance, three items form integration, one item reflects timeliness, explaining $16.249 \%$ of the variance, three items represent completeness, explaining $7.478 \%$ of the variance, three items belong to currency, explaining $6.677 \%$ of the variance. Three items measure flexibility, explaining $6.474 \%$ of the variance, three items represent format, explaining $5.391 \%$ of the variance, three items gauge accessibility, explaining $4.943 \%$ of the variance, three items assess accuracy, explaining $4.333 \%$ of the variance and two items reflect timeliness, explaining $3.790 \%$ of the variance. Lastly, the total variance of $76.592 \%$ clearly explains the nine-factorstructure of the independent variables. 
Table 1: Demographic information

\begin{tabular}{|c|c|c|c|}
\hline & Description & Frequency & Percentage \\
\hline \multirow[t]{2}{*}{ Gender } & Male & 99 & $49.5 \%$ \\
\hline & Female & 101 & $50.5 \%$ \\
\hline \multirow[t]{4}{*}{ Age } & Below 30 years & 103 & $51.5 \%$ \\
\hline & 31 to 40 years & 70 & $35.0 \%$ \\
\hline & 40 to 50 years & 24 & $12.0 \%$ \\
\hline & 51 years and above & 3 & $1.5 \%$ \\
\hline \multirow[t]{4}{*}{ Race } & Malay & 147 & $73.5 \%$ \\
\hline & Chinese & 36 & $18.0 \%$ \\
\hline & Indian & 16 & $8.0 \%$ \\
\hline & Others & 1 & $0.5 \%$ \\
\hline \multirow[t]{5}{*}{ Education Level } & Master's Degree & 19 & $9.5 \%$ \\
\hline & Bachelor's Degree & 50 & $25.0 \%$ \\
\hline & Diploma & 64 & $32.0 \%$ \\
\hline & High School Certificate & 57 & $28.5 \%$ \\
\hline & Others & 10 & $5.0 \%$ \\
\hline \multirow[t]{6}{*}{ Employment Status } & Student & 31 & $15.5 \%$ \\
\hline & Private Sector & 49 & $24.5 \%$ \\
\hline & Self-Employed & 48 & $24.0 \%$ \\
\hline & Government Sector & 59 & $29.5 \%$ \\
\hline & Retired & 7 & $3.5 \%$ \\
\hline & Others & 6 & $3.0 \%$ \\
\hline \multirow[t]{3}{*}{ Monthly Income } & RM10k-RM15k & 4 & $2.0 \%$ \\
\hline & RM5k-RM10k & 24 & $12.0 \%$ \\
\hline & Below RM5k & 172 & $86.0 \%$ \\
\hline
\end{tabular}

A principal component factor analysis with Varimax rotation was used to determine the factor dimensionality of user intention. The KMO value of 0.638 indicates that the items are interrelated to each other. Meanwhile, Bartlett's Test of Sphericity shows a significance value with Chi Square approximation 284.807 ( $p<0.001)$, indicating the significance of correlation matrix and appropriateness of factor analysis. Lastly, the total variance explained of $76.301 \%$ indicates a clear three-item-structure of the variable.

Table 2: The relationship between IQ and User Intention

\begin{tabular}{|c|l|c|c|c|c|c|c|c|}
\hline No. & Variables & Mean & SD & $\mathbf{1}$ & $\mathbf{2}$ & $\mathbf{3}$ & $\mathbf{4}$ & $\mathbf{5}$ \\
\hline 1 & Intention & 3.87 & 0.63 & $(0.797)$ & & & & \\
\hline 2 & Completeness & 3.85 & 0.60 & $0.325^{* *}$ & $(0.835)$ & & & \\
\hline 3 & Format & 3.72 & 0.59 & $0.233^{* *}$ & $0.243^{* *}$ & $(0.777)$ & & \\
\hline 4 & Accuracy & 3.51 & 0.62 & 0.029 & 0.018 & 0.109 & $(0.887)$ & \\
\hline 5 & Currency & 3.67 & 0.57 & 0.065 & 0.117 & $0.187^{* *}$ & $0.350^{* *}$ & $(0.857)$ \\
\hline
\end{tabular}

Table 2 displays the correlation results and the mean scores of the five variables, namely completeness, format, accuracy, currency, and user intention. The results of Pearson correlation analysis show that user intention has a weak positive relationship 'with 
completeness $\left(r=0.325^{* *}, p<0.01\right)$ and format $(r=0.233, p<0.01)$. However, user intention has no significant relationship with accuracy $(r=0.029, p>0.05)$ and currency $(r=0.065, p>0.05)$.

Table 3: The relationship between SQ and User Intention

\begin{tabular}{|c|l|c|c|c|c|c|c|c|c|}
\hline No. & Variables & Mean & SD & $\mathbf{1}$ & $\mathbf{2}$ & $\mathbf{3}$ & $\mathbf{4}$ & $\mathbf{5}$ & $\mathbf{6}$ \\
\hline 1 & Intention & 3.87 & .63 & $(0.797)$ & & & & & \\
\hline 2 & Reliability & 4.38 & .64 & $-0.269^{* *}$ & $(0.960)$ & & & & \\
\hline 3 & Accessibility & 3.89 & .52 & $0.369^{* *}$ & 0.012 & $(0.734)$ & & & \\
\hline 4 & Flexibility & 3.67 & .58 & $0.362^{* *}$ & -0.027 & $0.470^{* *}$ & $(0.759)$ & & \\
\hline 5 & Integration & 3.26 & .82 & $0.418^{* *}$ & $-0.336^{* *}$ & $0.325^{* *}$ & $0.404^{* *}$ & $(0.751)$ & \\
\hline 6 & Timeliness & 3.19 & .49 & 0.138 & 0.120 & $0.252^{* *}$ & $0.273^{* *}$ & 0.130 & $(0.617)$ \\
\hline
\end{tabular}

Table 3 shows the results of the correlation analysis and the mean scores of the six variables including reliability, accessibility, flexibility, integration, timeliness, and user intention. The results of the Pearson Correlation analysis show that user intention has a weak significant positive relationship with accessibility $(r=0.369, p<0.01)$, flexibility $(r=0.362, p<0.01)$ and integration $(r=0.418, p<0.01)$. Furthermore, user intention has a weak significant negative relationship with reliability $(r=-0.269, p<0.01)$, however, no significant relationship with timeliness $(r=0.138, p>0.05)$.

\section{Implications of the Study}

Service providers should ensure that the system provided meets the consumers' requirements. In this context, completeness and format of the SST is important to ensure the users will not face difficulty while using it and what more important is to ensure that the customers will use it again. The format must be easy to understand for all kind of users. This includes the language used that is appropriate to all. Besides that, the system used in SST must be reliable and accessible at the convenience of the users. Service providers must provide SST that are flexible and can be integrated with other systems or applications that can reduce the users' time while using it. The SSTs are always changing to suit current demand; therefore, service providers must always update their customers about any new changes. The findings will help the organization recognize the user's behaviour in using the SST services. Using the findings, service providers can devise the right strategies to attract customers and to expand the SST services to other branches in the future. Furthermore, the current users will influence others to use the services through positive words of mouth. Therefore, to make customers intend to repeat using the services, they must be satisfied with the services first. Making customers happy and pleased with what they get is vital, as it can lead to repeat usage and become loyal to the organization. After implementing the right strategies and upgrading the SST, it is expected that service providers can offer high quality services to the public.

\section{Suggestions for Future Research}

It is suggested future researchers to conduct multiple regression analysis to measure the effect of information and system quality toward user intention to use SST. Besides that, future researchers are also recommended include other industries in their studies such as transportation and banking. Currently, the transportation industry has provided a few SST facilities for its customers. At the airport, users can use SST while checking in. Similarly, the 
banking industry is also providing SST for its customers by providing ATM and CDM. Including various service industries in the study will be able to generalize the findings. Besides, future researchers can also use interview methods or focus group approach for data collection. By having direct and in-depth conversation with the respondents, the researchers might obtain more precise and reliable data which relay detailed information about personal customer's opinion and perception (Salkind, 2006). The study should be replicated to other courier service companies in Malaysia. It can ensure that the findings can be generalized fully throughout Malaysia. Despite that, the management of the participating company can improve the SST services. Based on the results of the study, it is recommended that the company needs to improve the information and quality services of the SST as one of the ways to attract more users. However, this study also anticipates that the usage of SST among customers will increase because of Covid-19 pandemic. During the time of pandemic, customers have limited opportunity to engage in face-to-face counter service. As such, using SST is the best solution to ensure business transaction can be performed. It is therefore recommended to conduct a similar study during the time of pandemic or post-pandemic to see the consistency of the findings.

\section{Conclusion}

As a conclusion, the result showed only six of the dimensions meet the necessary criteria to be significantly associated with user intention; namely, completeness, format, reliability, accessibility, flexibility, and integration. Accuracy, currency, and timeliness do not significantly associate with user intention. It can be presumed that the independent variables comprising completeness, format, reliability, accessibility, flexibility, and integration could influence user intention towards using SST. However, further analysis is recommended to prove this assumption.

\section{References}

Bailey, J. E., \& Pearson, S. W. (1983). Development of a tool for measuring and analyzing computer. Management Science, 29(5), 530-545.

Baykasoğlu, A., \& Özbakır, L. (2008). Analyzing the effect of flexibility on manufacturing systems performance. Journal of Manufacturing Technology Management, 19(2), 172 193.

Cheng, W., Harris, J., and Patterson, P. G. (2012). Customer choice of self- service technology: The roles of situational influences and past experience. Journal of Service Management, 23(1), 54-78.

Collier, J. E., \& Barnes, D. C. (2015). Self-service delight: Exploring the hedonic aspects of selfservice. Journal of Business Research, 68(5), 986-993.

Davis, F. D., Bagozzi, R. P., \& Warshaw, P. R. (1989). User acceptance of computer technology: A comparison of two theoretical models. Management Science, 35(8), 982-1003.

Delone, W. H., \& McLean, E. R. (2002). Information systems success revisited. Proceedings of the th International Conference on System Sciences (HICSS-35'02), Hilton Waikoloa Village, Island of Hawaii, HI, IEEE Computer Society, 7-10 January.

DOSM. (2019). Department of Statistics Malaysia. https://www.dosm.gov.my, Department of Statistics Malaysia Official Portal. Date Retrieved 21 December 2019.

Hair, J. F., Black, W. C., Babin, B. J., Anderson, R. E., \& Tatham, R. L. (2006). Multivariate data analysis. New Jersey: Pearson International Edition. 
Hala, A. K., \& Habin, L. E. E. (2013). E-government systems success and user acceptance in developing countries: The role of perceived support quality. International Journal of e-Business And e-Government Studies, 3(2), 69-78. https://www.theborneopost.com/2018/07/13/pos-malaysia-instructed-to-considerinitiatives-to-assist-postal-workers/

Mafabi, S., Nasiima, S., Muhimbise, E. M., Kaekende, F., \& Nakiyonga, C. (2017). The mediation role of intention in knowledge sharing behavior. VINE Journal of Information and Knowledge Management Systems, 47(2), VJIKMS-02-2016-0008. https://doi.org/10.1108/VJIKMS-02-2016-0008

MCMC. (2018). Annual Report 2018. https://www.mcmc.gov.my/skmmgovmy/media/General/pdf/MCMC-2018_ENG.pdf MCMC. (2019). Annual Report 2019. https://www.mcmc.gov.my/skmmgovmy/media/General/pdf/MCMC-2019_ENG.pdf

Meuter, M. L., Ostrom, A. L., Roundtree, R. I., Bitner, M. J. (2000). Self-service technologies: Understanding customer satisfaction with technology-based service encounters. Journal of Marketing, 64(3), 50-64.

Narteh, B. (2015). Perceived service quality and satisfaction of self-service technology: The case of automated teller machines. International Journal of Quality \& Reliability Management, 32(4), 361-380.

Pos Malaysia Berhad. (2017). Pos Laju launches prepaid dropbox service. http://www.thesundaily.my/news/1846123. Date Retrieved 21 December 2017.

Salkind, N. J. (2006). Statistics for people who (think they) hate statistics: The Excel Edition, 106.

Webster-Doyle, T. (1991). Why is everybody always picking on me?, Vermont: Atrium Society.

Weijters, B., Rangarajan, D., Falk, T., \& Schillewaert, N. (2007). Determinants and outcomes of customers' use of self-service technology in a retail setting. Journal of Service Research, 10(1), 3-21.

Wixom and Todd. (2005). A theoretical integration of user satisfaction and technology acceptance. Information Systems Research 16(1), 85-102. 